\title{
EFFICIENCY OF BIOFLAVONOID QUERCETIN AND RNA-CONTAINING DRUG SODIUM NUCLEINAT IN COMPLEX TREATMENT OF PATIENTS WITH MYOCARDIAL INFARCTION AND FUNCTIONAL LIVER DISORDERS
}

\section{SKUTECZNOŚĆ KWARTECYNY I NUKLEINATU SODU ZAWIERAJĄCYCH RNA SODU W KOMPLEKSOWYM LECZENIU PACJENTÓW Z ZABURZENIAMI MIOKARDIALNYMI I ZABURZENIIAMI FUNKCJONALNYMI WĄTROBY}

\author{
Mykola Shved $^{1(A)}$, Olena Prokopovych ${ }^{1(B, C, G)}$, Sofiya Lypovetska ${ }^{1(E)}$, Svitlana Heryak $^{1(D)}$, \\ Yaroslav Kitsak $^{1(\mathrm{~F})}$
}

${ }^{1}$ I. Horbachevsky Ternopil State Medical University; Ministry of Public Health, Ukraine

\author{
Authors' contribution \\ Wkład autorów: \\ A. Study design/planning \\ zaplanowanie badań \\ B. Data collection/entry \\ zebranie danych \\ C. Data analysis/statistics \\ dane - analiza i statystyki \\ D. Data interpretation \\ interpretacja danych \\ E. Preparation of manuscript \\ przygotowanie artykułu \\ F. Literature analysis/search \\ wyszukiwanie i analiza literatury \\ G. Funds collection \\ zebranie funduszy
}

Tables: 2

Figures: 0

References: 16

Submitted: 2017 May 29

Accepted: 2017 Jul 27
Summary

Background. The study has shown that functional liver disorders develop in patients with MI, which requires correction.

Material and methods. The study involved 149 patients with acute MI. All examinations were repeated several times on the 1,14 and 28 day of the treatment.

Results. The patients with functional liver disorders have a higher incidence of epistenocardial pericarditis, arrhythmia and systolic dysfunction. They are characterised by highly activated lipid peroxidation and immunological disorders. A combined therapy with quercetin resulted in improving hemodynamics and reducing the manifestations of liver dysfunction. RNAcontaining drug significantly improved the immune status and reduced signs of immunoinflammatory syndromes.

Conclusions. 1.In patients with MI and functional liver disorders, the primary pathological process is characterised by significant violations of systolic and diastolic function of the heart, more frequent development of complications, activation of lipid peroxidation and secondary immunodeficiency. 2. The inclusion of bioflavonoid quercetin in the treatment of patients with MI helps to restore the antioxidant defence system, improve myocardial contractile function and reduce clinical laboratory manifestations of cytolytic and cholestatic syndromes in patients due to antioxidant and membrane stabilizing properties of the drug. 3 . The usage of the RNA-containing drug Nuclex improves immune reactivity, reduces symptoms of expressed mesenchymal-inflammatory and necro-resorptive syndromes in patients with MI and functional liver disorders.

Keywords: myocardial infarction, liver function, lipid peroxidation, quercetin, sodium nucleinat

\section{Streszczenie}

Cel pracy. Badanie wykazało, że zaburzenia funkcji wątroby występują u pacjentów z MI, co wymaga korekty.

Materiał i metody. W badaniu wzięło udział 149 pacjentów z ostrym MI, u których powtórzono wszystkie badania w 1, 14 i 28 dniu leczenia.

Wyniki. U pacjentów z funkcjonalnymi zaburzeniami czynności wątroby często występuje epistenokardialne zapalenie osierdzia, arytmia i dysfunkcja skurczowej. Obserwuje się też wysoki poziom peroksydacji lipidów i zaburzenia immunologiczne. Połaczona terapia z kwercetyną spowodowała poprawę hemodynamiki i zmniejszenie objawów dysfunkcji wątroby. Leki zawierające RNA znacząco poprawiły status immunologiczny i zmniejszały objawy zespołów immunomodulacyjnych.

Wnioski. 1.W przypadku pacjentów po zawale serca i z zaburzeniami czynności wątroby, pierwotny proces patologiczny charakteryzuje się upośledzeniem funkcji skurczowej i rozkurczowej serca, częstszym rozwojem powikłań, aktywacja peroksydacji lipidów i wtórnym niedoborem odporności. 2. Włączenie kwercetyny w proces leczenia pacjentów z MI pomaga przywrócić system odporności antyoksydacyjnej, poprawić funkcję kurczliwości mięśnia sercowego i zmniejszyć kliniczne objawy laboratoryjne zespołów cytolitycznych i cholestatycznych, co wynika z właściwości przeciwutleniających leku stabilizujące błonę. 3. Stosowanie leku Nuclex zawierającego RNA poprawia reaktywność immunologiczną, zmniejsza objawy zespołów mezenchymalnych i zapalnych oraz nekroreorpcyjnych u pacjentów z MI i tych z funkcjonalnymi zaburzeniami czynności wątroby.

Słowa kluczowe: zawał mięśnia sercowego, czynność wątroby, peroksydacja lipidów, kwercetyna, nukleinat sodu

Shved M, Prokopovych O, Lypovetska S, Heryak S, Kitsak Y. Efficiency of bioflavonoid quercetin and RNA-containing drug sodium nucleinat in complex treatment of patients with myocardial infarction and functional liver disorders. Health Prob Civil. 2017; 11(4): $293-299$. DOI: https://doi.org/10.5114/hpc.2017.71891

Address for correspondence / Adres korespondencyjny: Prokopovych Olena I. Horbachevsky Ternopil State Medical University, Voli Square, 1, Ternopil, 46000, Ukraine, e-mail: prokopovishoa@gmail.com, phone: +380 352524492

Copyright: (C) 2017 Pope John Paul II State School of Higher Education in Biała Podlaska, Mykola Shved, Olena Prokopovych, Sofiya Lypovetska, Svitlana Heryak, Yaroslav Kitsak. This is an Open Access journal, all articles are distributed under the terms of the Creative Commons Attribution-NonCommercial-ShareAlike 4.0 International (CC BY-NC-SA 4.0) License (http://creativecommons.org/licenses/by-nc-sa/4.0/), allowing third parties to copy and redistribute the material in any medium or format and to remix, transform, and build upon the material, provided the original work is properly cited and states its license. 


\section{Introduction}

Presently, the research efforts are focused on studying the basic mechanisms of developing and forecasting myocardial infarction (MI) in combination with co-morbid pathology, as well as optimizing treatment by differential therapeutic techniques that can limit the zone of necrosis, reduce the development of complications and improve the quality of life of patients after MI $[1,2,6]$. Due to extensive implementation in clinical practice of medical (thrombolytic therapy) and surgical methods of coronary revascularisation (percutaneous transluminal coronary angioplasty, coronary artery bypass surgery), mortality and frequency of chronic heart failure in the early period of MI have been reduced, and prognosis has improved. However, patients, who have been admitted later than 6 hours from the start of development of acute coronary syndrome or because of other reasons such as the presence of co-morbidity together with contraindications to fibrinolytic therapy, receive standard pharmacotherapy of MI, and their total mortality rate remains rather high (over 20\%) $[3,16]$.

It is known that reduced cardiac output due to systolic dysfunction of the left ventricle (LV) in MI leads to hypoperfusion and hypoxia of all organs and systems, including the liver. Our previous studies have shown that in MI functional liver disorders are manifested by cytolytic, cholestatic syndromes and impaired synthetic function of the liver, which need correction [8,14]. Hypoxia is known to activate lipid peroxidation, which is an alternative donor of active forms of oxygen in these conditions. However, these active radicals can induce a damaging effect on the cell membrane, exacerbate the disease, promote activation of an inflammatory immune response and hypercoagulation $[5,9,10]$.

\section{Objective}

The following work aimed to improve the existing treatment programmes of MI by a differentiated approach to the therapy, depending on the presence or absence of functional liver disorders.

\section{Material and methods}

The study was conducted in the Cardiology Department of Ternopil University hospital in the years 20122016 and included 149 patients with acute MI. On the first day of hospitalisation, physical examination, determination of cardiac biomarkers, lipidograme, coagulograme, electrocardiography in the conventional 12 leads were performed. Intracardial hemodynamics was assessed by echocardiography in B-mode on Aloka SSD 2000 (USA) on 3, 5, 10, 15 and 20 day of the research. End diastolic volume (EDV) and end systolic volume (ESV) of $\mathrm{LV}$, ejection fraction (EF) by Simpson method were defined. The active indexes of lipid peroxidation (LPO) and antioxidant system (AOS) were evaluated by the results of the plasma malondialdehyde (MDA) content of a coloured complex in photocolorimetry that were formed by the interaction of MDA with thiobarbituric acid in an acidic medium [13]; the concentration of SH-groups of blood in the reaction of n-mercurbenzol sodium, the activity of superoxide dismutase (SOD) in erythrocytes (KF 1.15.1.1) as the degree of inhibition restored nitrotetrazolio blue, the activity of catalase (CT) in erythrocytes (KF 1.11.1.6) - by the photocolorimetric method by the intensity of coloured complex formed during the interaction of hydrogen peroxide (H2O2) molibdate ammonium [7]. The immune system was studied according to the level of CD 3 , CD 4, CD 8 , CD 16 , CD 22 by immune-enzyme analysis using specific monoclonal antibodies produced by "Sorbent" LTD, Russia. The content of serum immunoglobulins A, G, M was determined by Manchini (radial diffusion in the gel). The functional status of the liver was evaluated according to the results of clinical and biochemical examinations (bilirubin, total protein, cholesterol, lipid fractions, prothrombin, alanin amino transferase (ALT), aspartic amino transferase (AST), gamma glutamiltransferase (GGT), alkaline phosphatase (AP), and the ultrasound examination of the liver.

The research was done in compliance with the Convention on Human Rights and Biomedicine by the European Council, Helsinki Declaration, and the recommendations of Bioethical Committee of National Academy of Medical Science of Ukraine.

STATISTICA (StatSoft, USA, v 6.0) was used for statistical analysis: the non-parametric statistics Wilcoxon T-criteria test for comparison of dependent values in two groups, and the Spearman's rank correlation to establish the existence and strength of relationships between different values. Statistically significant differences were considered at $\mathrm{p}<0,05$. The quantities were presented as the mean value of standard errors $(\mathrm{M} \pm \mathrm{M})$.

All investigations were repeated on the $14^{\text {th }}$ and $28^{\text {th }}$ day. The study group involved patients with a verified diagnosis of acute MI following the recommendations of the European Society of Cardiology (2010). The exclusion criteria included chronic liver diseases, viral hepatitis, alcohol abuse history, prolonged intake of hepatotoxic drugs, cancer, severe acute left ventricular failure (IV functional class by Killip), and cardiac decompensation. 
The mean age of the examined persons was $59.9 \pm 7.6$ years: $37(24.8 \%)$ at the age of 45 years, $53(35.5 \%)$ 46 - 65 years old, and 59 (39.7\%) patients over 65 years. The group consisted of 110 men (73.8\%) and $39(26.2$ $\%)$ women. The most significant risk factors visible in patients were hypertension - in 103 persons (69.5\%), hypercholesterolemia - in 69 (5.4\%), diabetes mellitus and obesity in equal proportion 29 (19.5\%) patients. $84.6 \%$ of the women were in postmenopausal period. Finally, $29.8 \%$ of the patients ( $43.6 \%$ men) smoked for 5 and more years.

Most patients (89 - 59.75\%) had STEMI, 24 (16.2\%) - NSTEMI, whereas 36 patients (24.2\%) had repeated MI.

Depending on the identified functional liver disorders, the patients were divided into 2 groups. The main study group included 107 persons with acute MI and functional liver disorders. The control group consisted of 42 patients with severe MI but without functional liver disorders. In both groups, the patients were comparable in age, sex, and size, localisation and clinical course of MI. Also, depending on the method of treatment, each group consisted of three subgroups. The patients of the first subgroup received standard therapy, including direct anticoagulants, antiplatelet agents, beta-blockers, ACE inhibitors, nitrates and statins. The second subgroup additionally received bioflavonoid quercetin (Corvitin) $500 \mathrm{mg}$ IV within 10 days [4,11].

The complex treatment of patients of the third subgroup consisted of immunomodulatory and antioxidant product RNA (Nuclex) $1.5 \mathrm{~g}$ a day for 20 days. Biological properties of exogenous RNA, in particular, stimulation of cell metabolism, reparative processes, activating the synthesis of endogenous nucleic acids, macroergic compounds, specific proteins and enzymes, increasing the ability of cells to mitosis, immunomodulatory and anti-inflammatory effect, are beneficial in MI [15].

The anti-inflammatory activity of RNA is implemented by inhibition of metabolism of free arachidonic acid, thereby providing membrane stabilisation and endothelium protective actions, including suspension of atherosclerotic plaques' destabilisation. Also, the RNA-containing drug regulates the activity of NO-synthase through the inhibition in cardiomyocytes and increase in the bloodstream and, as a consequence, induces constitutive nitric oxide synthesis, and provides antioxidant, anti-ischemic, antiplatelet, hematopoietic effects. The cardioprotective properties of RNA contribute to the improvement of the coronary and systemic circulation, systolic and diastolic LV function, increased the electrical stability of the myocardium, resulting in reduced mortality, an incidence of arrhythmias, post-infarction angina, the severity of heart failure.

The fibrinolytic therapy was not conducted in patients of the main and control groups.

\section{Results and discussion}

Uncomplicated MI was observed in 17 (40\%) patients of the control group. Patients with functional liver disorders had various complications of the primary disease (84 patients - $78.5 \%$ ). Epistenocardical pericarditis was significantly more often found in patients with functional liver disorders than in the control group (42 (39.3\%) vs. 8 (19\%)). The disturbance of rhythm or conduction, such as paroxysmal tachyarrhythmias, transient atrioventricular blockade and polymorphic extrasystoles, were also more frequently encountered in patients of the main group and significantly less in patients without functional liver disorders, i.e. 38 (35.5\%) vs. 9 (21.4\%). Also, aneurysm of the left ventricule was diagnosed in 17 (15.9\%) patients of the main group and 4 (9.5\%) patients of the control group. Acute heart failure was present in patients of both groups; however, Killip classes I and II were observed significantly more often in patients in the control group, whereas class III was significantly more often diagnosed in patients of the main group. It was found that pericarditis epistenocardica occurred more often in persons who were aged 45-65 years (in 24 (17.8\%) of the patients), whereas the aneurysm of the LV and arrhythmias were significantly more prevalent in persons of older age categories, respectively (in 7 (5.3\%) and 19 (13.4\%) patients).

Simultaneously, patients of both groups had a disturbance of systolic and diastolic function of the LV. More significant reduction of EF (42.12 $\pm 1.13 \%)$ and more pronounced remodelling of LV in the acute phase of MI were observed in patients of the main group compared with the control (EF - 48.23 $\pm 1,16 \%$ ). In particular, $\mathrm{LV}$ EDD was $5.62 \pm 0,21 \mathrm{sm}$ in the main group and $4.71 \pm 0,24 \mathrm{sm}$ in the control $(\mathrm{p}<0,05)$. Diastolic dysfunction was characterised by changes of isovolumic relaxation time (IVRT) in the main (63.23 $\pm 0,41 \mathrm{~ms}$ ) and control groups (68.12 $\pm 0,36 \mathrm{~ms}$ ) and deceleration time of early diastolic mitral flow (DT) $178.11 \pm 0,54 \mathrm{~ms}$ vs. $182.43 \pm 0,37 \mathrm{~ms}$.

After standard treatment of patients of the control group, significant improvement of hemodynamic parameters, in particular, increased EF, decreased LV EDD, increased IVRT, and decreased DT, were diagnosed in comparison with the patients who had functional liver disorders $(\mathrm{p}<0,05)$.

However, in patients of the main group after standard therapy, there was no significant recovery of systolic and diastolic function. Using quercetin or sodium nucleinate (RNA) have provided more rapid normalisation of indices of systolic and diastolic functions of the heart, which was significantly improved during the 28 
days of treatment in the main and in the control group. The linear dimensions of the heart cavities did not change dramatically, but positive dynamics of EF, LV EDD, IVRT and DT in comparison with initial indices were improved due to remodelling and restoration of the functional state of the areas of ischemia and hibernation of the myocardium (Table.1).

Table 1. Dynamics of systolic and diastolic cardiac functions in patients with MI during the proposed treatment programme $(\mathrm{M} \pm \mathrm{m})$

\begin{tabular}{|c|c|c|c|c|c|}
\hline Indices & No. & Before treatment & Standard treatment & Corvitin & Nuclex \\
\hline \multirow{2}{*}{$\begin{array}{l}\text { LV EDD, } \\
\text { sm }\end{array}$} & 1 & $5.62 \pm 0.21$ & $5.84 \pm 0.07$ & $5.23 \pm 0.18$ & $5.24 \pm 0.03$ \\
\hline & 2 & $4.71 \pm 0.08$ & $5.58 \pm 0.14$ & $5.53 \pm 0.12$ & $5.43 \pm 0.32$ \\
\hline \multirow{2}{*}{$\mathrm{E} / \mathrm{A}$} & 1 & $1.35 \pm 0.03$ & $\underline{1.03 \pm 0.04}$ & $\underline{1.31 \pm 0.03}$ & $1.51 \pm 0.04$ \\
\hline & 2 & $1.41 \pm 0.03$ & $1.19 \pm 0.05$ & $1.38 \pm 0.07$ & $1.58 \pm 0.09$ \\
\hline \multirow{2}{*}{$\begin{array}{l}\text { IVRT, } \\
\text { ms }\end{array}$} & 1 & $63.23 \pm 0.41$ & $68.13 \pm 2.10^{*}$ & $73.13 \pm 1.11^{*}$ & $73.49 \pm 1.26^{*}$ \\
\hline & 2 & $68.12 \pm 0.36$ & $73.21 \pm 1.26^{*}$ & $79.27 \pm 1.33^{*}$ & $78.17 \pm 2.13^{*}$ \\
\hline \multirow{2}{*}{$\begin{array}{l}\text { DT, } \\
\text { ms }\end{array}$} & 1 & $178.11 \pm 0.54$ & $164.26 \pm 4.66^{*}$ & $214.22 \pm 4.23^{*}$ & $192.28 \pm 4.02^{*}$ \\
\hline & 2 & $182.43 \pm 0.37$ & $184.62 \pm 4.35^{*}$ & $213.65 \pm 4.21^{*}$ & $198.22 \pm 3.65^{*}$ \\
\hline \multirow{2}{*}{$\mathrm{EF}, \%$} & 1 & $42.12 \pm 1.13$ & $\underline{43.28 \pm 0.23}$ & $49.68 \pm 0.32^{*}$ & $52.38 \pm 0.12^{*}$ \\
\hline & 2 & $48.23 \pm 1.16$ & $48.76 \pm 1.36$ & $51.62 \pm 1.62^{*}$ & $51.67 \pm 1.16^{*}$ \\
\hline \multirow{2}{*}{$\mathrm{OV}, \mathrm{ml}$} & 1 & $47.14 \pm 0.79$ & $\underline{49.26 \pm 2.29}$ & $51.43 \pm 1.20^{*}$ & $52.03 \pm 0.82^{*}$ \\
\hline & 2 & $52.88 \pm 1.62$ & $59.26 \pm 2.15^{*}$ & $59.68 \pm 1.56^{*}$ & $59.95 \pm 1.25^{*}$ \\
\hline
\end{tabular}

1.1.2 - MI with respective indices in patients with and without functional liver disorders;

2. underlined indices significantly differed from respective ones in the control group $(\mathrm{p}<0.05)$;

3. *- indices significantly differed from respective in patients who received standard treatment.

Changes in laboratory parameters in MI patients with or without functional liver disorders, depending on the methods of treatment are presented in Table 2 . The significant difference between all studied parameters in patients of the main and control groups was found in the initial state.

Table 2. Dynamics of laboratory indices of liver functional state in patients with MI during the proposed treatment programme $(\mathrm{M} \pm \mathrm{m})$

\begin{tabular}{|c|c|c|c|c|c|c|c|}
\hline Indices & $\begin{array}{c}\text { Day of } \\
\text { treat-ment }\end{array}$ & & $\begin{array}{c}\text { Standard treat- } \\
\text { ment }\end{array}$ & Corvitin & Nuclex & $\mathrm{P}_{1}$ & $\mathrm{P}_{2}$ \\
\hline \multirow{6}{*}{$\begin{array}{c}\text { Bilirubin, } \\
\text { mmol/l }\end{array}$} & \multirow{2}{*}{1 day день } & 1 & $24.61 \pm 1.1^{*}$ & $23.64 \pm 1.23^{*}$ & $24.3 \pm 1.22^{*}$ & $\mathrm{p}>0.05$ & $p>0.05$ \\
\hline & & 2 & $17.51 \pm 0.2$ & $17.93 \pm 4.43$ & $17.7 \pm 2.33$ & $\mathrm{p}>0.05$ & $p>0.05$ \\
\hline & \multirow{2}{*}{14 day } & 1 & $23.58 \pm 1.3^{*}$ & $20.26 \pm 1.52^{*}$ & $18.96 \pm 1.44^{*}$ & $\mathrm{p}<0.05$ & $\mathrm{p}<0.05$ \\
\hline & & 2 & $16.24 \pm 0.3$ & $17.7 \pm 3.24$ & $16.5 \pm 2.32$ & $\mathrm{p}>0.05$ & $p>0.05$ \\
\hline & \multirow{2}{*}{28 day } & 1 & $20.12 \pm 0.2^{*}$ & $\underline{18.51 \pm 2.12}$ & $\underline{17.83 \pm 1.42}$ & $\mathrm{p}<0.05$ & $\mathrm{p}<0.05$ \\
\hline & & 2 & $16.52 \pm \underline{0.2}$ & $16.23 \pm 2.13$ & $16.23 \pm 3.32$ & $\mathrm{p}>0.05$ & $\mathrm{p}>0.05$ \\
\hline \multirow{7}{*}{$\begin{array}{c}\text { ALT, } \\
\mathrm{mkmol} / \mathrm{l}\end{array}$} & \multirow{2}{*}{1 day } & 1 & $0.89 \pm 0.04^{*}$ & $0.91 \pm 0.02 *$ & $0.92 \pm 0.05^{*}$ & $\mathrm{p}>0.05$ & $\mathrm{p}>0.05$ \\
\hline & & 2 & $0.49 \pm 0.03$ & $0.54 \pm 0.03$ & $0.58 \pm 0.03$ & $\mathrm{p}>0.05$ & $\mathrm{p}>0.05$ \\
\hline & \multirow{2}{*}{14 day } & 1 & $0.86 \pm 0.02 *$ & $0.78 \pm 0.04^{*}$ & $0.76 \pm 0.05^{*}$ & $\mathrm{p}<0.05$ & $\mathrm{p}<0.05$ \\
\hline & & 2 & $0.43 \pm 0.02$ & $0.57 \pm 0.03$ & $0.68 \pm 0.03$ & $\mathrm{p}>0.05$ & $\mathrm{p}>0.05$ \\
\hline & \multirow{3}{*}{28 day } & 1 & $\underline{0.79 \pm 0.03^{*}}$ & $\underline{0.69 \pm 0.03}$ & $\underline{0.69 \pm 0.04}$ & $\mathrm{p}<0.05$ & $\mathrm{p}<0.05$ \\
\hline & & 2 & $0.42 \pm 0.04$ & $0.56 \pm 0.04$ & $0.68 \pm 0.05$ & $\mathrm{p}>0.05$ & $p>0.05$ \\
\hline & & 2 & $\underline{0.58 \pm 0.03}$ & $\underline{0.67 \pm 0.03}$ & $\begin{array}{c}0.64 \pm \\
0.03 \\
\end{array}$ & $\mathrm{p}>0.05$ & $p>0.05$ \\
\hline \multirow{6}{*}{ GGT, U/L } & \multirow{2}{*}{1 day } & 1 & $80.45 \pm 5.34^{*}$ & $81.23 \pm 3.23^{*}$ & $82.65 \pm 3.59 *$ & $\mathrm{p}>0.05$ & $\mathrm{p}>0.05$ \\
\hline & & 2 & $34.12 \pm 3.23$ & $32.24 \pm 2.54$ & $39.17 \pm 2.12$ & $p>0.05$ & $\mathrm{p}>0.05$ \\
\hline & \multirow{2}{*}{14 day } & 1 & $112.23 \pm 4.45^{*}$ & $88.96 \pm 4.12^{*}$ & $78.43 \pm 2.43^{*}$ & $\mathrm{p}<0.05$ & $\mathrm{p}<0.05$ \\
\hline & & 2 & $36.12 \pm 4.23$ & $34.23 \pm 3.12$ & $35.52 \pm 2.15$ & $p>0.05$ & $\mathrm{p}>0.05$ \\
\hline & \multirow{2}{*}{28 day } & 1 & $105.23 \pm 3.23^{*}$ & $\underline{43.11 \pm 2.43}$ & $42.18 \pm 2.31$ & $\mathrm{p}<0.05$ & $\mathrm{p}<0.05$ \\
\hline & & 2 & $37.32 \pm 2.34$ & $35.23 \pm 2.32$ & $42.42 \pm 3.14$ & $\mathrm{p}>0.05$ & $p>0.05$ \\
\hline
\end{tabular}




\begin{tabular}{|c|c|c|c|c|c|c|c|}
\hline \multirow{6}{*}{ AP, U/l } & \multirow{2}{*}{1 day } & 1 & $2.16 \pm 0.12 *$ & $2.18 \pm 0.38^{*}$ & $2.51 \pm 0.08^{*}$ & $\mathrm{p}>0.05$ & $p>0.05$ \\
\hline & & 2 & $1.21 \pm 0.21$ & $1.06 \pm 0.07$ & $1.14 \pm 0.05$ & $p>0.05$ & $\mathrm{p}>0.05$ \\
\hline & \multirow{2}{*}{14 day } & 1 & $2.45 \pm 0.21 *$ & $1.12 \pm 0.05$ & $1.09 \pm 0.06$ & $\mathrm{p}<0.05$ & $\mathrm{p}<0.05$ \\
\hline & & 2 & $1.31 \pm 0.33$ & $1.10 \pm 0.07$ & $1.07 \pm 0.06$ & $p>0.05$ & $p>0.05$ \\
\hline & \multirow{2}{*}{28 day } & 1 & $2.24 \pm 0.02 *$ & $\underline{1.09 \pm 0.04}$ & $\underline{1.08 \pm 0.07}$ & $\mathrm{p}<0.05$ & $\mathrm{p}<0.05$ \\
\hline & & 2 & $1.12 \pm 0.03$ & $1.01 \pm 0.05$ & $1.04 \pm 0.08$ & $\mathrm{p}>0.05$ & $p>0.05$ \\
\hline \multirow{6}{*}{$\begin{array}{c}\text { Cholesterol, } \\
\text { mmol/l }\end{array}$} & \multirow[b]{2}{*}{1 day } & 1 & $5.64 \pm 0.76^{*}$ & $5.76 \pm 0.67 *$ & $5.76 \pm 1.01^{*}$ & $\mathrm{p}>0.05$ & $p>0.05$ \\
\hline & & 2 & $3.45 \pm 1.21$ & $3.58 \pm 0.76$ & $3.65 \pm 0.65$ & $p>0.05$ & $p>0.05$ \\
\hline & \multirow[b]{2}{*}{14 day } & 1 & $4.32 \pm 0.43$ & $4.32 \pm 0.14$ & $4.54 \pm 0.74$ & $\mathrm{p}>0.05$ & $\mathrm{p}>0.05$ \\
\hline & & 2 & $3.56 \pm 0.16$ & $3.74 \pm 0.69$ & $3.13 \pm 0.65$ & $\mathrm{p}>0.05$ & $p>0.05$ \\
\hline & \multirow[b]{2}{*}{28 day } & 1 & $\underline{4.23 \pm 0.32}$ & $\underline{4.24 \pm 0.38}$ & $\underline{4.13 \pm 0.68}$ & $\mathrm{p}>0.05$ & $p>0.05$ \\
\hline & & 2 & $3.24 \pm 0.24$ & $3.48 \pm 0.85$ & $3.26 \pm 0.54$ & $\mathrm{p}>0.05$ & $p>0.05$ \\
\hline \multirow{6}{*}{ LDL, mmol/l } & \multirow[b]{2}{*}{1 day } & 1 & $3.87 \pm 0.06^{*}$ & $3.41 \pm 0.07 *$ & $3.42 \pm 0.06^{*}$ & $p>0.05$ & $p>0.05$ \\
\hline & & 2 & $2.54 \pm 0.06$ & $2.49 \pm 0.05$ & $2.45 \pm 0.05$ & $\mathrm{p}>0.05$ & $p>0.05$ \\
\hline & \multirow[b]{2}{*}{14 day } & 1 & $3.67 \pm 0.07 *$ & $3.06 \pm 0.05$ & $2.73 \pm 0.06$ & $\mathrm{p}>0.05$ & $\mathrm{p}>0.05$ \\
\hline & & 2 & $2.12 \pm 0.05$ & $3.42 \pm 0.05$ & $2.32 \pm 0.04$ & $\mathrm{p}>0.05$ & $p>0.05$ \\
\hline & \multirow{2}{*}{28 day } & 1 & $3.45 \pm 0.06^{*}$ & $\underline{2.65 \pm 0.04}$ & $\underline{2.37 \pm 0.04}$ & $\mathrm{p}<0.05$ & $\mathrm{p}<0.05$ \\
\hline & & 2 & $2.24 \pm 0.08$ & $3.12 \pm 0.06$ & $2.45 \pm 0.06$ & $p>0.05$ & $\mathrm{p}>0.05$ \\
\hline
\end{tabular}

Note: 1.2 - respective data in patients with or without functional liver disorders

- underlined parameters are significantly different from similar indices on 1 day of treatment $(\mathrm{p}<0.05)$

- p1 - significance of indices between patients who received standard treatment and with Nuclex;

- p2 - significance of indices between patients who received standard treatment and with Corvitin;

-* - significance between indices of the main and control groups $(\mathrm{p}<0.05)$

Functional liver disorders in patients with IM at the beginning of treatment were manifested, primarily, by the presence of cytolysis syndrome, which is associated with damage to membranes and internal hepatic cholestasis. In addition, patients of the main group had significantly more often dyslipidemia, which was manifested by hypercholesterolemia and increase of atherogenic fractions of lipoproteins (LP). A moderate decrease in total protein level in this group of patients showed a violation of the synthetic function of the liver.

Initially, the patients of the main group had more profound inhibition of T-cell and greater activation of B part of the immune system, immune response on modified treatment compared with the patients of the control group. These patients had a significant decrease in total $\mathrm{T}$ lymphocytes, T-helpers, T-suppressors and T-killers, the increased level of B-lymphocytes, immunoglobulins A, M, G, and increasing concentrations of CIC. The obtained changes of immunograme indicated the development of secondary immunodeficiency on the background of functional liver disorders in these patients.

At the same time, patients with acute MI and functional liver disorders initially had significantly higher activation of POL because of depression of theantioxidant system, manifested by a decreased level of ceruloplasmin and sulfhydryl groups compared with the same parameters in the control group. The obtained data have an essential role in the development and progression of pathological changes in the liver and significantly affect the course of MI [12].

It was noted during the observations that the usage of quercetin (Corvitin) had a favourable influence on the course of MI, by decreasing complications, compared with the group of patients, who received standard therapy. In patients with MI and functional liver disorders after two weeks of complex treatment with the inclusion of quercetin, frequency epistenocardical pericarditis was decreased by $33.2 \%$, symptoms of heart failure by 63.9 $\%$, the development of early post-infarct angina $22.2 \%$.

The frequency of rhythm and conduction disturbances significantly decreased in patients of the main group treated with quercetin. In particular, the frequency of sinus tachycardia on the 28 day, decreased by $63.9 \%$, conduction disturbances by $16.7 \%$, ventricular extrasystole by $41.7 \%$, and supraventricular premature beats by $52.8 \%$ less compared to the original data.

On comparing the effectiveness of the standard treatment and the proposed modified (using Nuclex and Corvitin) in patients of the main and control groups, it was revealed that normalisation of cytolytic and 
cholestatic syndromes was achieved in the group of the patients receiving combined therapy for 14 days. At the same time, the hepatoprotective effect was not achieved in patients receiving standard treatment. A significant difference between the indices of cholestasis, cytolysis and dyslipidemia was preserved.

The proposed treatment, including RNA containing drug, leads to a significant increase in T-part of immune system: the level of CD3 lymphocytes increased to $35.2 \pm 1,2 \%$, CD8 killers to $16.4 \pm 0.21 \%$ and CD16 suppressors - up to $12.2 \pm 0,2 \%$, decreased the number of cells CD22 $12.41 \pm 0.12 \%$ and the CIC in $178.32 \pm 2.43$. In general, it was proven that there was a restoration of immune reactivity in patients with MI and impaired liver function.

In the group of patients receiving comprehensive treatment with the addition of antioxidant quercetin, a significant improvement of immunological parameters was shown at the end of treatment; however, compared with the group treated with the RNA containing drug, a significant difference remained. Thus, in patients with MI with impaired liver function after the treatment with quercetin signs of immunodeficiency were observed, such as inhibition of T-system lymphocytes (32.12 $\pm 0.17 \%)$, increased activity B lymphocytes $(13.63 \pm 0.32 \%)$ and a high concentration of immunoglobulins and CIC (267.21 $\pm 0.26 \mathrm{U})$.

The various antioxidant efficiency of the proposed methods of treatment was found. After the course of treatment including RNA drug, the level of monovoltine was significantly decreased, but remained above average, suggesting the predominance of the activity of peroxidation processes over the protective capabilities of the antioxidant system (ceruloplasmin $392.2 \pm 2.3 \mathrm{mg} / \mathrm{l}$ ). However, in the main group additionally treated with quercetin, the level of malondialdehyde significantly decreased to $4.43 \pm 1.23 \mathrm{mg} / \mathrm{ml}$, compared with patients receiving standard therapy or treatment with Nuclex. The significantly increased activity of endogenous antioxidant enzymes, particularly ceruloplasmin, glutathione, catalase and superoxide dismutase, was observed in the group treated with quercetin.

Having analysed the results of our research, we may conclude that functional liver disorders significantly affect the course of acute MI, which was accompanied by a significant frequent quantity of complications. These patients had a severe disturbance in antioxidant defence system and activation of lipid peroxidation. Depression of cellular immunity was observed in all patients; however, in patients with liver disorders, it was significantly more pronounced. The standard treatment was effective only in patients MI without functional liver disorders. Thus, for patients with IM and violations of the functional state of the liver, standard therapy was not effective enough, which was the justification for the differential inclusion of drugs Nuclex or Corvitin in the programme of the standard therapy, depending on the prevalence of immunological changes or activation of POL processes.

\section{Conclusions}

1. In patients with MI and functional liver disorders, the main pathological process is characterised by significant violations of systolic and diastolic function of the heart, more frequent development of complications, activation of lipid peroxidation and secondary immunodeficiency.

2. The inclusion of bioflavonoid quercetin in the treatment of patients with MI helps to restore the antioxidant defence system, improve myocardial contractile function and reduce clinical laboratory manifestations of cytolytic and cholestatic syndromes in patients due to antioxidant and membrane stabilising properties of the drug.

3. The usage of RNA-containing drug Nuclex improves immune reactivity, reduces symptoms of expressed mesenchymal-inflammatory and necro-resorptive syndromes in patients with MI and functional liver disorders.

\section{References:}

1. Alyavi AL, Kenzhayev ML, Alyavi BA. The effect of corvitin on reversible left ventricular myocardial dysfunction in patients with acute coronary syndrome with ST segment elevation. Practical Angiology. 2009; 1: 55-59.

2. Bartekova M, Carnicka S, Ondrejcakova M, Breier A, Rgerova T. Acute treatment with polyphenol quercetin improves postischemic recovery of isolated perfused rat hearts after global ischemia. Can J Physiol Pharmacol. 2010; 88: 465-471.

3. Bartekova J, Pancza D, Barancik M, Ravingerova T. Cardioprotective Effects of Quercetin Against IschemiaReperfusion Injury Are Age-Dependent M. Physiol. Res. 2016; 65 (Suppl. 1): S101-S107.

4. Gregory S, Kelly ND. Quercetin. AMR 2011; 16: 2: 172-94.

5. Jin HB, Yang YB, Song YL, Zhang YC, Li YR. Protective roles of quercetin in acute myocardial ischemia and reperfusion injury in rats. Mol. Biol. Rep. 2012; 39(12): 11005-11009. 
6. Hicks JJ, Montes-Cortes DH, Cruz-Dominguez MP, Medina-Santillan R, Olivares-Corichi IM. Antioxidants decreasere perfusion induced arrhythmias in myocardial infarction with ST-elevation. Frontiers in Bioscience: a Journal and Virtual Library. 2007: 12: 2029-2037.

7. Korolyuk MA, Ivanova AI, Majorova IT. Method of catalase activity examination. Lab Delo. 1988;1:16-9 (in Russian).

8. Kozhukhov S, Parkhomenko A. Myocardial protection by intravenous 5-lipoxygenase inhibitor Quercetin administration before primary angioplasty in patients with acute myocardial infarction: short-term results an open blind randomized trial. J. Amer. Coll. Cardiology. 2007; 49(9) (Suppl. A): 226A.

9. Lutai YM, Parkhomenko AN, Ryzhkova NA, Gavrilenko TI, Irkin OI, Kozhukhov SM, et al. Therapy with an intravenous inhibitor of 5-lipoxygenase quercetin on endothelial function, the severity of systemic inflammation and pro-oxidative stress in acute myocardial infarction with ST elevation. Emergency medicine. 2016; 1(72): 111-119.

10. Moybenko AA, Parkhomenko AN. An efficiency of the water-soluble form of quercetin (Corvitin) in the treatment of acute coronary syndrome with ST segment elevation. Journal of the AMS of Ukraine. 2003; 9(2): 361-370.

11. Parkhomenko A, Kozhukhov S, Gurjeva O. Clinical efficacy of intravenous lipoxygenase inhibitor quercetin in patients with acute ST-segment elevation myocardial infarction: results of a prospective randomized openlabel trial. Seminars in Cardiology. 2005; 11(4): 154-158.

12. Parkhomenko AN. Metabolic therapy, or cardioprotection in ischemic heart disease: results and perspectives. Ukr. Med. Journal. 2008; 4(66):15-19 (in Ukrainian).

13. Stalnaya I, Garishvili T. Method for determination of diene conjugation of unsaturated higher fatty acids. Moscow: Medicina; 1977. p. 43-44 (in Russian).

14. Shved NI, Prokopovych EA. Treatment of patients with myocardial infarction with violations of the functional state of the liver. Galitskiy Medicinal Herald. 2011;2: 130-134 (in Ukrainian).

15. Shved NI, Tkachuk ZY, Prokopovych EA. Features of the immune response and changes in lipid peroxidation in the acute stage of myocardial infarction in patients with functional disorders of the liver. Bulletin of Scientific Research. 2010; 2: 21-24 (in Ukrainian).

16. Yellon DM, Hausenloy DJ. Myocardial Reperfusion Injury. N Engl J Med. 2007; 357: 1121-35. 